\title{
Strategic Corporate Responsibility and Sustainability Performance Management Model
}

\author{
Adeyemi Ademola Egbeleke ${ }^{1}$ \\ ${ }^{1}$ Risk and Efficiency Management Information System Solutions, United Kingdom \\ Correspondence: Adeyemi Ademola Egbeleke, Risk and Efficiency Management Information System Solutions, \\ United Kingdom. E-mail: yemiegbeleke@yahoo.co.uk
}

\author{
Received: January 28, 2014 Accepted: February 21, 2014 Online Published: May 27, 2014 \\ doi:10.5539/jms.v4n2p92 URL: http://dx.doi.org/10.5539/jms.v4n2p92
}

\begin{abstract}
The cross industries overall business performance instability is non-exclusive of the prevalence of corporate responsibility and sustainability (CRS) performance instabilities. Contributing to CRS performance instabilities, are deficiencies of existing CRS descriptive frameworks to support delivery of CRS performance management. This is in the light of stakeholder's demands for business implementation of economic multiplier oriented CRS programmes. To address the problem of CRS performance instability, the Strategic Corporate Responsibility and Sustainability (CRS) Performance Management Model is built to enable business engagement in delivery of economic multipliers programmes to create CRS value convertible into Cash Value Added (CVA) for distribution among stakeholders and for business survival. The results from pilot testing indicate capability of the model's integrative processes to deliver CRS performances that are verifiable and acceptable to stakeholders. However this requires business leader's CRS Values as a driving force.
\end{abstract}

Keywords: strategy, corporate responsibility and sustainability, performance management

\section{Introduction}

There are no shortages of theoretical frameworks describing business and society relationships in terms of expected responsible and sustainable performances. Despite the plethora of corporate responsibility and sustainability (CRS) oriented frameworks, their descriptive tendency has been found not to be fit for purpose with respect to changing the nature of CRS programmes. As cross industries cases of CRS performance instability are increasing, stakeholders are demanding business to go beyond philanthropic activities to the implementation of the economic multipliers CRS programme. Thus the deficiency of existing CRS frameworks to guide CRS performance management are clearly manifested (Nelson, 2003; Katsoulakos \& Katsoulacos, 2006b, 2007; Visser, 2013). The consensus from both academics and practitioners is the need for a stakeholder led integrative CRS performance management model (Katsoulakos \& Katsoulacos, 2006b, 2007; Bhattacharyya, 2008; European Commission, 2011; Corporate Citizenship, 2012; Visser, 2006, 2013; Egbeleke, 2013, 2014). There have been academic responses to the challenge of developing operable CRS performance frameworks to address the prevalence of CRS performance instability (Egbeleke, 2013, 2014). While these attempts have been significant in tackling issues such as the creation of shared value by way of linking CRS programmes to the operations value chain (Porter \& Kramer, 2006), determining of strategic CRS programmes from options of CRS initiatives (Egbeleke, 2014; Bhattacharyya, 2008), CRS performance measurement and reporting (Katsoulakos \& Katsoulacos, 2006b; Egbeleke, 2013), and transformative CRS and profitability reference models (Katsoulakos \& Katsoulacos, 2007; Visser, 2013). There have not been any CRS frameworks that integrate all the components aforementioned above that deals with various issues of CRS performance management. This paper attempts to fill this gap by building an operable Strategic CRS Performance Management Model and pilot testing the model's capability to deliver cash value added (CVA) for stakeholders.

\subsection{Research Objective}

To build a strategic CRS performance management model through innovative integration of existing CRS frameworks that have addressed key issues relating to CRS performances. 


\subsection{Research Question}

1) Can economic multiplier's CRS programme design and implementation contributes to the creation of CRS values that inspire customer stakeholders brand loyalty and re purchase generation?

2) Can a strategic CRS performance management model support the creation of CRS Value convertible through business core competencies and dynamic capabilities into cash value added?

\subsection{Literature Review}

The reality of global prevailing social, economic and environmental problems has impacted the nature of programmes that businesses are expected to get involved with by stakeholders. Stakeholder's demands are constantly pushing for changes in business- society engagement programmes from philanthropically dominated practices to more developmental oriented practices (Nelson, 2003; Katsoulakos \& Katsoulacos, 2006b; Harvard University, 2007; Corporate Citizenship, 2012; Visser, 2006, 2013). The changing nature of business- society programmes was captured by the International Business Leadership Forum-IBLF as they identified eight economic multipliers area of concentration for CRS programmes that can be implemented especially in developing countries (Nelson, 2003). Furthermore, Katsoulakos and Katsoulacos (2006a) emphasise on some of the economic multipliers CRS programmes as they expressed that companies need to accept a new proactive role in shaping the future of the world by supporting and developing the social dimension of globalisation. They also when necessary need to take a leading role in organising responsible supply chains; investing in innovative health, energy and environmental products; establishing business models that will work in poorer countries; transferring knowledge and improving conditions and infrastructure in developing countries; and engagements in partnerships and dynamic coalitions to strengthen the world's sustainability capacity. Even though, it was argued that economic opportunity programmes as highlighted above are where firms have the greatest potential to create "shared value" or value for both business and society, if linked with the operational value chain (Harvard University, 2007; Porter \& Kramer, 2006). Still many in the academic, not-for- profit and business fields continue to ask is the economic multiplier programmes CSR? However, describing the wide variety of activities companies undertake, or are being asked to undertake to enhance the net impact of business in the society might not all be covered by the generic definition of CSR. Therefore, this paper's point of view is that economic multipliers and its enhancer's is not CSR! It is Corporate Responsibility and Sustainability CRS (Harvard University, 2007)! CRS is about enabling companies to incorporate the creation of social, environmental and economic values into core strategy and operations. Thus improving management of business risks and opportunities whilst enhancing long-term social and environmental sustainability which is critical for business survival and sustainability in this present complex and interconnected trading world (Cranfield University, 2013; Egbeleke, 2010).

EC (2011) view small and medium enterprises as more likely to engage in economic multiplier CRS programmes for delivery of shared public value because the CRS strategy process are informal and intuitive. However, some practitioners view that economic multipliers CRS programmes offers in theory, the creation of shared value for both communities and companies, but express that it is so hard to articulate the benefits inside most companies (Harvard University, 2007). This is because CRS performance measurement remains a challenge (Visser, 2013). The need to focus on CRS performance was echoed through the result of Accenture and UNGlobal compact-2010 survey of 766 Companies CEO's as 34\% cited lack of CRS performance recognition by financial market as a key barrier to achieving their CRS goals (Lacy, Cooper, Hayward, \& Neuberger, 2010). This brought forwards the problem of CRS key performance indicator -KPI's argued to be crucial for CRS performance measurement and reporting (Henriques, 2010; Egbeleke, 2013). The summary points are that businesses cannot articulate the share value benefits from CRS programme implementations because they can't measure CRS performance, and the CRS performance they can't measure, they can't manage (Visser, 2013). Thus, leading to cross-continental and cross industries breakdown of CRS values with widespread of CRS performance instability as consequences (Katsoulakos \& Katsoulacos, 2006a, 2006b; Egbeleke, 2009, 2010; Schwab, 2010; Mallenabaker, 2013).

There have been attempts at development of CRS models such as CSR Pyramid, Stakeholders theory, Corporate Social Performance Framework, Triple Bottom Line reporting, Bottom of the Pyramid (BOP) Model, Strategic CSR concept, and very lately the CSR DNA model to guide CRS performance delivery. But all remain descriptive in nature and this is inclusive of the CSR DNA model that was argued to have integrated what has been learnt till date from the other models listed to present a holistic description of transformative CRS (Visser, 2013). The descriptive orientation of existing frameworks made them unsuitable to provide guidance for CRS performance measurement, reporting and management. CRS performance management frameworks need to 
integrate the full lifecycle of CRS strategy formulation, implementation, evaluation and evolution incorporating stakeholder participation to ensure it contributes to overall business performance stability (Katsoulakos \& Katsoulacos, 2006b, 2007). Because the existing CRS frameworks are not producing strategic information that would enable CRS Values to be formed, business leaderships are setting up of rules guiding decision making about business right and wrong, should and shouldn't and good and bad actions are deficient (Nelson, 2003). These deficiencies clearly manifest with lack of leadership emotional investment in CRS programmes implemented by companies as many of such programmes did not make strategic sense (Bhattacharyya, 2008). Likewise, the narrow perspectives for changes that need to be made to drive CRS performances improvements affect business leadership's ability to promote responsible business with managers and young professionals who are the next generation of business leaders (Nelson, 2003). As a result, voluntary business -driven and multi-stakeholder CRS programmes that are business responses to stakeholder's demands to share responsibility for world sustainability by way of addressing value chain operational negative externalities within industries neither achieves CRS performance improvement nor develops capacity for significant contribution to sustainable development target delivery (Fransen, 2012). This provides a justification for the need for an integrative CRS performance management model (Katsoulakos \& Katsoulacos, 2006b). To buttress the position of this paper to attempt the building of an integrative framework tagged "Strategic CRS Performance Management Model" needed to correct CRS performance instability, a review of cross- industries cases of CRS values breakdown leading to performance instability would suffice and are presented in the next section.

\subsubsection{CRS Values Breakdown Leading to CRS Performance Instability}

The gradual erosion of values in the processes of business creation of value for their shareholders has been observed over the years. This erosion of societal values has progressed to a complete breakdown of CRS values particularly in the business world and has necessitated the call for a fundamental rethink of the development of our morals and our ethical norms in relation to regulatory mechanisms that underpin our economy, politics and global interconnectedness, if social peace is not be undermined (Schwab, 2010). However the current set up of the entrepreneurial system is in such a way that trading strategies management decision-making processes are completely decouple from the responsibility of managers from their own risk-taking and CRS principle violations (Schwab, 2010; Egbeleke, 2010). Thus, means enterprise is no longer an organic community noted for creation of goods and services for the common good; but has metamorphosed into a functional "profit-generating machine" by which the entrepreneurial system becomes perverted (Schwab, 2010). The breakdown of CRS values lead to CRS performance instability demonstrated by social crisis negative outcomes. To explain this, a brief review of recent events in the financial services, oil and gas, pharmaceuticals and readymade garment industries would suffice.

\subsubsection{Financial Services Industry Performance Instability}

Egbeleke (2009) argued that the banking crisis leading to economic recession in 2008 was due to strategic governmental policies to relax financial services industry regulations. However, Schwab (2010) argued as noted earlier that it was the breakdown of values by reason of unethical practices based on excessive risk taking within the financial services industry that caused the global economic recession. However the year 2012 brought into the limelight how bank traders have been artificially fixing the price of money by distorting the London Interbank-Offered Rate (Libor). There is no doubt Barclays and others understood the importance of Libor in the financial industry and the consequences of acts that distort its calculation on rate integrity with risk of serious harm to other market participants and many organisations that includes schools and municipal authorities hedging against interest rates risk. Yet Barclays took a leadership role in Libor fixing conspiracy with Citigroup, JPMorgan, Bank of America and others to manipulate the rate figures. The reported fixing of Libor rates reverberated globally with far reaching effects not only in the derivatives markets and for an estimated US\$360 trillion of assets, mostly consumer debts tied to Libor (MallenBaker, 2012; DiStefano, 2012). So, after over 51 years of the first major business Enron price fixing scandals, the then cowboy mentality of trading driven by short-term profits as influenced by compensation and bonus schemes with utter disregard for risk-adjusted returns is still prevalent in the 21st century (DiStefano, 2012).

\subsubsection{Oil and Gas Industry Performance Instability}

The strategic position of the oil and gas industry within the global economy cannot be overemphasised. Likewise, social -environmental damages the industry is causing to the global community are irreparable. The US Gulf of Mexico Transocean and British Petroleum (BP) rig explosion is a notable example of a complete CRS values breakdown as the oil spill caused the deaths of 11 people, devastating damages to the gulf, its wildlife, its people and their livelihoods (Robertson, 2010). For CRS principles violations US\$6.9 billion was paid in case 
settlement fines for environmental damages that should have carried the potential fine of an estimated US \$21billion for the spill under the Act and BP paid a civil fine of \$525 million for misleading investors (Krauss \& Schwartz, 2012; Schwartz, 2013).

Another on-going example that shows serious CRS values breakdown and consequences of performance instability is the Niger Delta region of Nigeria Oil companies-Communities-Government conflicts. The consequence is "Guerrilla Warfare" conflict situations that have turned oil company security spending into a bottomless pit. An analysis of Shell's global security expenditure between 2007 and 2009 reveals that Shell spent at least $\$ 1$ billion on security. Shell spent more on security in the Niger Delta than in the Americas, EU and Russia combined with almost $40 \%$ of this; some $\$ 383$ million which was spent in securing Shell's operations in the Niger Delta region. This security cost estimate does not include security expenditure on the Shell operated Liquefied Natural Gas (LNG) plant in Bonny. Nor does it include an estimated annual \$200 million of 'community development' funds, which are frequently distributed to groups that threaten Shell's operations, sparking serious violent conflicts. The same high cost of security applies to Chevron, ExxonMobil, Eni/Agip and other oil companies operating in Nigeria (Amunwa, 2012). This shows commitments to verifiable CRS performances alternatives foregone by oil and gas companies is at a high financial cost, the operating infrastructure and human costs as security spends on private security companies, regular payments to government forces in Nigeria, direct cash distribution to some members of communities and this has only exacerbated the conflict, and proved incapable of protecting Shell's and others pipeline infrastructure facilities and personnel (us-eia, 2012; Amunwa, 2012).

\subsubsection{Pharmaceutical Industry Performance Instability}

The practice of providing incentives to doctors to promote the use of drugs is common within pharmaceutical industry. So, GlaxoSmithKline's (GSK) provision of extravagant entertainment for doctors to promote the use of its drugs is not an exception. Even though, it is reported that the company CEO at the period of CRS principles violation was focused heavily on the role of the company in society. However, the management took a very aggressive approach to ensure CRS practice compliance from its employees. They took disciplinary actions against any employee and terminated their employment if they didn't get the application of Company corporate responsibility policy application right. Yet, GlaxoSmithKline (GSK) was fined \$3bn in the US for selling drugs for unapproved uses amongst other breaches in 2012 during the same period of harsh enforcement of CRS practice (Mallenbaker, 2012).

\subsubsection{Transnational Ready Made Garment Industry Performance Instability}

For many years there have been widespread allegations of unethical practices within the supply chain of transnational garment industry (Egbeleke, 2010). The transnational garment supply chain situation has progressively got worse from poor wages, to fires and then to the total factory building collapse in 2013. It was reported that 1,100 factory workers were dead at Rana Plaza in Bangladesh. A show of appallingly dangerous working conditions in Bangladesh's clothing factories, for which some very big retailers lack values to take leadership for its renovations despite all the profits made from operating within the RMG supply chain (NewYork Times, 2013). Many believe that the problem of worker's safety within the transnational garment supply chain is neither lack of policy statement on workers safety nor factory audit and inspection by Brands operators. The truth is that it costs more to produce under good working conditions than in bad working conditions. It was argued that the price pressure mounted by cloth retail companies on their suppliers to deliver rock bottom prices pushes factories to cut corners to cut costs. The implication of retailer demands for lower prices effectively ensured the safety goals contained in Brands policy statements are virtually ignored by factories. Also, it was reported that leading apparel corporations with reference to Wal-Mart and Gap dismissed the idea that they should pay higher prices to fund the renovation of dangerous factories in Bangladesh during a fire safety meeting held 2011 (Nova, 2012). Nonetheless, while the retailers have left the issues of victim compensation unattended, they have put in place the Accord on Fire and Building Safety signed by global unions and over 80 fashion brands and retailers. The Accord is a five-year programme aimed at ensuring health and safety measures, including the assessment and remediation of structural integrity and fire safety in factories used by the signatories (International Labour Organisation-ILO, 2013). Why the accord now after 1100 dead factory workers? Why not accord at the fire safety meeting held 2011 to keep them alive?

All the above cases present a strong evidence of CRS values breakdown with performance instability as consequences. Thus, solutions to performance instability require a two prong approach emphasising long term performance optimisation rather than short term profit maximisation and developing responsiveness capabilities in terms of CRS strategy, knowledge management and reporting. To action this solution an attempt is made to 
build a strategic CRS performance management model to facilitate a change from agency to stakeholder approach that aligns CRS programmes with corporate strategies integrated into value chain activities to deliver Cash Value Added-CVA inform of financial, social and environmental values contributing to CRS performance stability (Nelson, 2003; Porter \& Kramer, 2006; Katsoulakos \& Katsoulacos, 2006a, 2007; Bhattacharyya, 2008; Egbeleke, 2013, 2014).

\subsubsection{The Building of Strategic Corporate Responsibility and Sustainability Performance Management Model}

The CRS programmes and performance issues discussed earlier in this paper pointed out key components of the strategic CRS performance management model and what the model should help achieve. Thus the model should provide (1) process guidance for transparent CRS programme implementation and a performance verification tool; (2) stakeholders driven methodology that integrate social, economic and environmental factors to establish sustainable business operations; (Katsoulakos \& Katsoulacos, 2006b; EC, 2011); (3) mechanism for decision on choice of CRS programmes that makes strategic sense to sustainable business operations with capability of managing CRS programme investment risk and delivery of shared value (Porter \& Kramer, 2006; Katsoulakos \& Katsoulacos, 2006a; Bhattacharyya, 2008, Egbeleke, 2014). To proceed with development of the model, a review of existing scholastic works related to operational tools for CRS performance management was carried out. Egbeleke (2013) framework that reveals the importance of corporate responsibility and sustainability key performance indicators (CRS KPI's) and integrated impact assessment (IIA) data gathering and reporting methodology in delivery of corporate responsibility and sustainability performance reporting system is found notable. The innovative way of operationalizing the strategic CRS programme selection decision process through Set Theory Oriented Strategy CRS programme Axiom Filter Elements integrated with firm value chain operational activities is found useful. This operational tool is considered to have satisfied the mechanism for decision making on choice of CRS programmes that make strategic sense to sustainable business operations (Bhattacharyya, 2008; Egbeleke, 2014). Even though, the Strategic CRS programmes design and implementation is embedded within logical decision making mechanism to produce sustainability value (Egbeleke, 2014). Still CRS competencies strategies are required to engage with company's core competencies and dynamic capabilities in the processes of conversion of sustainability value into sustainable innovation for the creation of cash value added (Nelson, 2003; Katsoulakos \& Katsoulacos, 2007). So, as suggested by Egbeleke (2014), an integrated impact assessment driven corporate responsibility and sustainability performance measurement and reporting system is integrated within the Strategic CRS programmes design and implementation framework to develop a Strategic Corporate Responsibility and Sustainability (CRS) Performance Management Model in Figure 1 below.

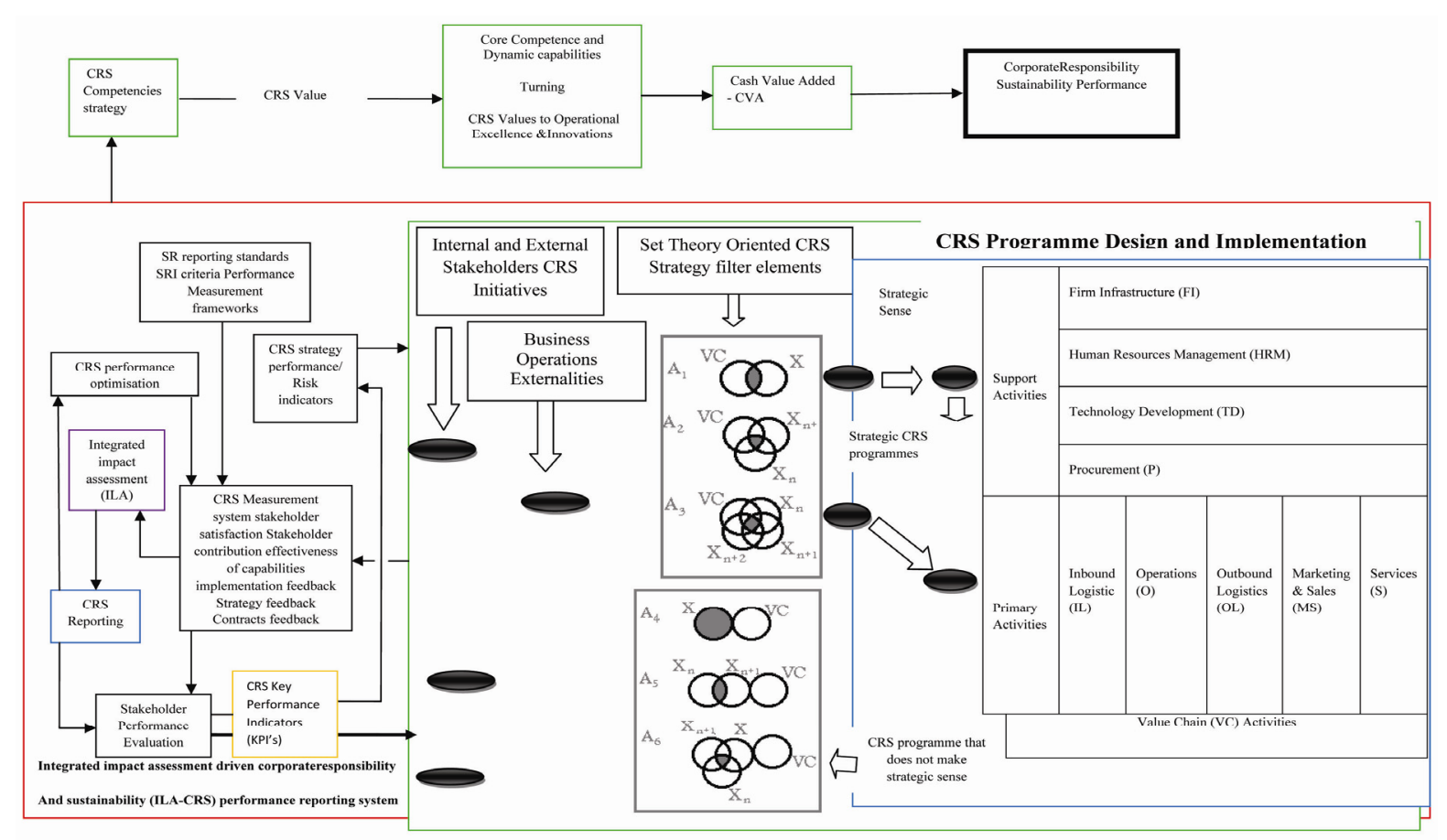

Figure 1. Strategic corporate responsibility and sustainability (CRS) performance management model 
Furthermore, core competencies and dynamic capabilities components of the Figure 1 model strategically position the companies to understand stakeholder's perception on companies responsibilities and sustainability strategies and performance in such a way that sustainability innovation leverages other resources along the value chain to deliver superior economic/marginal value (perceived customer benefits and cost reduction) (Katsoulakos \& Katsoulacos, 2007). With a strategic CRS performance management model in place, attempt is made to pilot test its CRS performance delivery capability. The data analysis and results are presented in the next section.

\section{Research Methodology}

The research started with a review of existing CRS theoretical frameworks and those that were found to be operable were integrated to build a Strategic CRS performance management model. Next field work was carried out to answer the research question posed by this paper, through which indication of the model's capability to deliver CRS performance stability is found. The field survey was guided by a mixed-methods sequential explanatory design which consists of two distinct strands of data collection and analysis with quantitative followed by a qualitative phase as informed by inference overflow link (Creswell, Plano Clark, Gutmann, \& Hanson, 2003; Tashakkori \& Teddlie, 2003; Ivankova, Creswell, \& Stick, 2006). Quantitative (numeric) data was collected from the administered structured questionnaire on customers -stakeholders CRS - retail brand loyalty perception. The retail brand loyalty perception survey was hosted on survey console platform, an independent survey organisation agency. Through the Survey console data collection platform, survey was sent to respondents in parts of the city of Bradford in West Yorkshire, United Kingdom. The data analysis from Survey console platform was based on 89 responses received out 200 expected. However, inferences from the survey console re-presented quantitative data analysis enabled Haqs, a local retail brand to be identified based on the result that this local business commands $4 \%$ of Customer Groups as their Retail Brands Choice. An in depth qualitative interview was conducted with Haqs to explain statistical results and validate the strategic CRS performance management model's capability to deliver CVA. The data was collected through semi-structured open ended questionnaires used for conduction of the interview from a one (Individual) business leader perception. Content analysis was carried out on qualitative data set to produce meta-inference's (Weber, 1990; Tashakkori \& Teddlie, 2003). The summary findings and its implications for CRS objectives was discussed to reach a conclusion on acceptability of this paper's theoretical contribution to both management theory and practice (Ivankova et al., 2006).

\section{Data Analysis and Result Presentation}

To assert the view point that a strategic CRS performance management model can provide theoretical guidance and be developed into an operational tool for delivery of stakeholder accepted CRS performances, this paper proceeded to conduct a Customer-stakeholder-CRS brand loyalty perception survey with focus on the retail industry. The below tables presented result of analysis of survey.

Table 1. Percentage level of repurchases by customer groups

\begin{tabular}{ll}
\hline How many times have you repurchased from this retail store brand? & Percentage of Response \\
\hline Once a month Customers & $12 \%$ \\
$2-5$ times a month Customers & $50 \%$ \\
More than five times a month Customers & $38 \%$ \\
\hline
\end{tabular}

Table 1 shows a significant level of repurchase across the customers groups. This indicates that the voice of the customer on CRS strategies in relation to CRS programme design and implementation by retail brands cannot be ignored, if CRS performance stability within the supply chain of retail industry is to be achieved. 
Table 2. Customers' perception of CRS programmes by percentage response

\begin{tabular}{|c|c|c|c|}
\hline Customer Perception of CRS Programmes & $\begin{array}{l}\text { Percentage of } \\
\text { Yes response }\end{array}$ & $\begin{array}{l}\text { Percentage of } \\
\text { No response }\end{array}$ & $\begin{array}{l}\text { Percentage of I } \\
\text { can't say } \\
\text { response }\end{array}$ \\
\hline $\begin{array}{l}\text { Do you agree that retail companies should commit to social responsibility, } \\
\text { community, and green economic development projects? }\end{array}$ & $91 \%$ & $3 \%$ & $6 \%$ \\
\hline $\begin{array}{l}\text { Does Retail Brand/Company commitments to doing any of the social } \\
\text { responsibility, community, and green economic development projects listed } \\
\text { appeals to you, and inspires loyalty to Brand? }\end{array}$ & $67 \%$ & $10 \%$ & $23 \%$ \\
\hline $\begin{array}{l}\text { Do you know what social responsibility, community, and green economic } \\
\text { development projects you choice retail store are committed to? }\end{array}$ & $30 \%$ & $52 \%$ & $18 \%$ \\
\hline $\begin{array}{l}\text { Have you donate money in support of your local retail store social responsibility, } \\
\text { community, and green economic development projects before? }\end{array}$ & $12 \%$ & $82 \%$ & $6 \%$ \\
\hline
\end{tabular}

Based on the importance of voice of customers to CRS strategies, table 2 above reveals customer's approval for CRS programme implementation with a sizeable percentage of customers saying it would inspire brand loyalty. While customers that have gone extra mile to donate money in support of their retail brand CRS projects strengthen the view that CRS programme can drive brand loyalty. But customers that do not know anything about CRS programmes of retail brands are equally high.

Table 3. Customers' perception of IBLF economic multipliers CRS programme

\begin{tabular}{ll}
\hline IBLF Economic Multipliers CRS Programme & Percentage Response \\
\hline Generate investment and income & $13.50 \%$ \\
Produce safe products and services & $17.25 \%$ \\
Create jobs & $20.75 \%$ \\
Invest in human capital & $11.25 \%$ \\
Establish local business linkages & $12.25 \%$ \\
Spread international business standards & $7.50 \%$ \\
Support technology transfer & $7.00 \%$ \\
Build physical and institutional infrastructure & $10.50 \%$ \\
None & $0.00 \%$ \\
\hline
\end{tabular}

Furthermore, table 3 shows customer's approval of retail brands commitments to any of IBLF economic multipliers CRS programme, although job creation rank highest.

Table 4. Retail brands choice by customer groups

\begin{tabular}{ll}
\hline Respondents Choice Retail Brand & Percentage of Response \\
\hline Asda & $15 \%$ \\
Tesco & $29 \%$ \\
Morrison & $13 \%$ \\
Haqs & $4 \%$ \\
Lidl & $9 \%$ \\
Co-operatives & $3 \%$ \\
Sainsbury & $5 \%$ \\
Marks and Spencer & $1 \%$ \\
H\&M & $1 \%$ \\
New Look & $1 \%$ \\
River Island & $1 \%$ \\
Chattan & $1 \%$ \\
Farm foods & $1 \%$ \\
AL Halal & $1 \%$ \\
Convenient store & $1 \%$ \\
Multiple Retail Brands Choice & $13 \%$ \\
\hline
\end{tabular}


Table 4 above simply reveals customer choices from multinational retailers to a one store retail operation in the local area. None are exempted by customers from CRS programmes commitments. Also, there is sizeable percentage of customers that does not have a single choice of retail brand.

However, some customer's responses were able to mention some CRS programmes of their choice retailers, such as "Schools projects; water projects in Kenya; buildings schools, helping the widow, borehole water for local communities in Africa etc". One respondent mention "Active Youth"; another one expressed as follows "By purchasing of goods and services to certain amounts helps get vouchers for certain projects -Let grow projects providing free gardening equipment's to schools (Morrisons)". While other customer respondents expressed what type of CRS initiatives they expect their retail brand to be committed to such as "Create new opportunities for millions of young people around the world; Help and encourage our colleagues and customers to live healthier lives; Lead in reducing food waste globally; Reducing Impact on the Environment by aiming to be a zero-carbon business by 2050 and to use scarce resources responsibly; including in the supply chain; Supporting Local Communities; Future Farmer Foundation".

The above customer responses reveal that the majority of retailer's projects currently undertaken or expectation falls within IBLF economic multipliers CRS programmes. Likewise, the results show that CRS programme can drive or inspire brand loyalty. Where brand loyalty with evidence of high repurchases outcome is marginal value in form of cash value added (CVA).

An attempt was made to pilot test the ability of strategic CRS performance management model processes to ensure CRS value creates CVA. Also, the model manages CVA sharing between employees, governments, providers of capital and local communities. And support risk management through retained CVA in the business or invested for future growth and benefit of stakeholders in the future (Nelson, 2003).

Therefore, an in-depth interview on the capability of strategic CRS performance management model to deliver CVA was conducted with the Founder and CEO of Haqs foods retail supermarket. A brief company background gathered during the interview with extracts of responses in relation to all components of the model is analytically presented below:

Haqs food retail supermarket is a one branch retail store operation located in the city of Bradford, United Kingdom. It is a small enterprise established as a family business in July in 2000 employing 24 staff with a steady annual turnover of $£ 3$ million (pounds). The food produce sold are sourced through agents or suppliers importing such as vegetables from Kenya and Ghana; spices from India and Pakistan; and rice comes from India and America. Haqs store does not have direct dealings with the communities that produce these products. Yet, they have number of CRS projects engagements with communities and villages in Kenya, Africa. The following questions were posed by the researcher to Haqs CEO with responses as follows:

\section{Researcher: What sort of CRS projects are you involved with?}

Haqs: We are involved with Kenya, giving free education to children, bringing water to the villages. We have two schools up and running. So, villages where people have got water problem and we give water to them. So it's mainly giving water and free education. So we have not just these two main projects, we have a lot of other little projects going on at the same time. We help some people who have got very severe illnesses; like somebody had cancer some time ago, we help to bear the cost of treatment. So we have other little bits as well going on, but our main concentration is the water well.

Cross analysis of Haqs responses above with IBLF economic multipliers CRS programmes reveals the water and school projects falls under "build physical and institutional infrastructure" enjoying $10.5 \%$ of customers stakeholders approval as per earlier survey result reported in this paper. Likewise, there are other social -welfare and philanthropic CRS programmes engagements.

Researcher: Who are the people that decide on choice CRS projects you do and why your choice projects goes to Kenya?

Haqs: As I said earlier we have understanding of needs of communities in Kenya, so it is based on our preexisting knowledge of community projects needs of the people there. We decide ourselves, I mean us the directors, but we only concentrate on Kenya, nowhere else.

Researcher: Are there others stakeholders including your employee, community's leaders, suppliers, customers that are involved in decision of choice and where you company implement the projects?

Haqs: No. 
Researcher: I can see that you have displayed pictures of your projects your company implemented in Kenya both in front of your store and as well as at strategic point of sale areas within your store, are you trying to report your CRS project activities performance through this form of public display?

Haqs: No, the only reason why we have displayed that is to create awareness between our customers. It's partly to our customers, that they see the project, they see awareness from this. Of course, some of them do help; they contribute whether it's a pound or 10 pounds or whatever, towards our water project. So we collect enough money every month to keep on building a new well. So there is a new water well build every month.

Researcher: Do you have any kind of performance indicator in place for measuring your company CRS projects performance progress towards set target the projects delivery need to meet?

Haqs: No, we haven't. We are a family business, we don't set target for our community projects delivery. May be that would be ideal for big businesses to have in place.

Even though, Haqs does not consider their strategic display of CRS project activities publicly as a form of reporting. However, a look at the below display of CRS images reveals a form of Ethical Advertisement practices by Haqs.

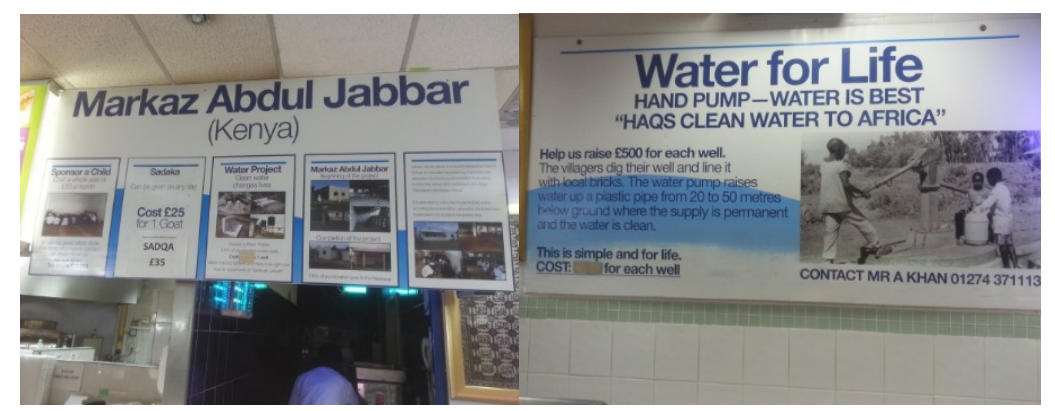

Image 1. Haqs retail supermarket in store point of sale display of CRS project in Kenya

Based on this discussion above, the paper proceeds to test Haqs strategic CRS program design and implementation in relation to delivery of CVA.

Researcher: Looking at the model, which of or all of the factors do you think would have affected or influence your choice of CRS projects?

Haqs: I think the linkage of our CRS projects with our value chain would be beneficial.

Researcher: In what ways?

Haqs: It would be good for the community that are producing the foods we retail to get extra more back through our project and for us we would be happy to help a lit bit more the farmers, if we knew exactly where the produce was coming from. However if our CRS project goes to the farming communities, I think our customers that contributes tokens would appreciate it as well. So, if we knew exactly where the village growing our produce, then we would do something in that village.

Researcher: What this model is trying to say is that for CRS programme to be strategic, it must at least contribute to the value chain, do you agree?

Haqs: Yeah, I agree. Linking of CRS projects to value chain would be more beneficial to us and many other businesses. But for us until we find out exactly which village it's coming from, what are the conditions, what they need to work, what their facilities are, then we could make things better.

This willingness of Haqs to link their CRS projects with their produce procurement by way of delivery of infrastructure projects that directly benefits the farming communities in Kenya is stepping into Ethical Trading . Thus, leading to how CVA is created.

Researcher: Looking at the CRS projects you are implementing, does it affect your profitability in any way?

Haqs: Yes, because all the running cost for the projects are paid from the business. So, about $4-5 \%$ of our profit goes towards the projects a year. 
Researcher: Does your business expect or get value from the implementation of this project either directly or indirectly?

Haqs: No, it doesn't -- at the end of the day we are not doing it to get any reward here on earth. We are not looking for rewards here from the people. So these projects and other contributions are really for long-term, for the future -eternal when we are dead and gone. That's what we are looking at. That's the only reason behind it. So we strongly believe that what you spend in God's way, help the poor, who are less fortunate than yourself, you get rewarded for that. So that's our reward. That's what we are looking for, but not rewards from any contemporary.

Researcher: You are a small business, 3 million turnovers; you are going into infrastructure project-education, and water, social welfare project, whereas big businesses, multinationals are finding it difficult to take decision to do such projects. Again, is it because you are a family business that's made it easier for you to take such decision?

Haqs: I think only -- I will give you an example, we have many suppliers we deal with who are very big compared to ourselves. We might be on 3 million turnovers, they are on 50 million turnovers, and these are huge suppliers of food. Now, I think at the end of the day it's God, if He wants you to do something, you will do it, and He doesn't give everybody the ability to do it. We are small, well thank God; He has given us opportunities to do a lot more. So just recently, in our Ramadan period, when we were fasting, we contributed food to nearly 6,000 people a day for the full month. And that's not a big cost 120 pounds per day. Now, we spoke to our suppliers and we thought 30 days it's easier; I deal with over a 100 suppliers. So we spoke to about eight or nine and we said, look, you can contribute for one day, it's only 120 pounds. And not a single one did. They said, times are hard, we have got bills coming in, insurance is really difficult, and diesel is going up. So, I personally think, it's whether God wants you to do it, you do it. So big companies, they are very tight. The bigger they are, they will not spend the money. So it's just one of those things. So some people have the conscience. At the end of the day we believe that everything given to us is from God, it's not ours, and we can spend a little bit, even if you give a little bit, that's nice. Some people don't. They think no, that's my money, I can't give anything. Now, a lot of people are selfish; we are just hoping we are not.

Research: So it's about your values. I think that's what it comes down to.

Haqs: It's your personal values.

The analysis of the above discuss reveals the importance of CRS values at board of director level. With strategic CRS performance management model capability to create CVA from integration of CRS programmes with operational value chain can lead to development of CRS values. The discussion of summary findings and its implication is presented in the next section below.

\section{Discussion of Findings}

\subsection{Stakeholder's CRS Initiatives Diversity}

This relates to arrays of initiatives and propositions convertible to CRS programmes. The survey results show diversity of the stakeholder's proposed CRS initiatives open to business and Haqs range of CRS programmes in Kenya did confirm CRS initiatives diversity (Visser, 2013; Egbeleke, 2014). The test of IBLF economic multiplier CRS initiative through a stakeholder-Customer perception survey show significant approval of CRS programme design along this line from the result. Thus, answering any question about CRS categorisation of such projects. Further, the survey results show sizable number of donors expressing support for economic multiplier CRS projects. Haqs' collection of donations from customers to support the company funding of the water project in Kenya is a confirmation of strong support for business engagement in building physical and institutional infrastructure project and others listed by IBLF (Nelson, 2003; Harvard University, 2007; Visser, 2013).

\subsection{Value Chain Integrations Factor in Determining Strategic CRS Programme}

The CRS initiatives emanating from the stakeholder-customers survey show some propositions that are value chain activities inclined and others CRS initiatives that are not. While discussion analysis of the interview with Haqs did reveal their CRS projects have been unconsciously integrated into the company value chain. The business consideration of water and school projects as a main focus implies they are strategic CRS programmes. Other social-welfare and philanthropic CRS projects are not regarded as strategic. Again, because feeding people during Ramadan fasting does not make strategic sense to the Haqs "Suppliers" value chain activities for it to warrant the suppliers company CRS investment, thus Ramadan's CRS initiative was dropped (Porter \& Kramer, 2006; Katsoulakos \& Katsoulacos, 2006a; Bhattacharyya, 2008; Egbeleke, 2014). Therefore, this finding 
provides confirmation for set theory oriented filter elements with contribution to value chain as the main intersection for determining which CRS initiatives becomes strategic CRS programme and those that does not make strategic sense (Egbeleke, 2014).

\subsection{Strategic CRS Performance Management Model Improvement of CRS Communication}

The customer-stakeholder survey revealed that a total of $70 \%$ of customers did not know or can't say anything about CRS programmes of retail brands. This finding provides a confirmation of problems with companies CRS performance reporting (Henrique, 2010, Egbeleke, 2013). However, findings from a study of the ways Haqs communicate CRS performances has enabled stakeholder's engagement indirectly in the legitimisation of CRS programme choices and decision process and impact assessment driven CRS programme design and implementation reporting. This is evidenced in project activities images of a public showing of delivery progress achieved. Haqs has managed to use its innovative way of CRS performance communication as a sustainable source of competitive advantage (Katsoulakos \& Katsoulacos, 2007; Egbeleke, 2013, 2014). Undoubtedly, Haqs' CRS strategies has delivered advantage-creating knowledge and advantage-creating stakeholder relations ensuring mutual trust and reciprocity; common understanding of shared CRS values and goals between the business and its stakeholders (Katsoulakos \& Katsoulacos, 2007). While Haqs expressed that Egbeleke's (2013) IIA-CRS performance measurement and reporting system operationalization might not be suitable for their type of small enterprises-family business as a formal statutory CRS reporting is not required. However, they view that big businesses that are required to do formal CRS reporting would find it useful. The usefulness in terms of fostering shared CRS values and goals, enable early identification of risks, vulnerabilities and contribution to corrective and mitigation actions in relation to improve product and services offering from the point of view of investors, customers, employees, suppliers and the society at large (Katsoulakos \& Katsoulacos, 2006a, 2007; Egbeleke, 2013).

\subsection{Strategic CRS Performance Management Model Delivery of CVA}

Haqs' CRS project engagements discussion analysis did reflect informal strategic CRS performance management model processes to a significant extent. The informal process supported the choice of water and school as the company's main CRS programme (EC, 2011). The survey results showed $91 \%$ of customer's approval for business enterprises of any size and ownership commitments to social responsibility, community and green economic development projects. This validates Haqs' involvement with the building of physical infrastructure projects (Nelson, 2003; Katsoulakos \& Katsoulacos, 2006a). 67\% of customers surveyed reveal that doing economic multipliers CRS projects inspire their brand loyalty. Thus, apart from other factors, it could be inferred from the findings that Haqs has innovatively created and showcased a responsible desire to build its retail brand within the local community of Bradford. Therefore, Haqs' CRS performance image displays is a form of ethical advertisement meant for public notice for customers especially to convey business CRS values information, invite patronage and seek for donations in support of the business choice of CRS programme (HHCL \& Partners, 2006). Furthermore, Haqs show a strong willingness to deliver projects to villages in Kenya where its produces are coming from, a move towards brand ethical trading. The pursuance of ethical trading CRS initiatives can only strengthen their ethical advertisement position and reduce brand reputations damage risk (HHCL \& Partners, 2006; Egbeleke, 2010).

At present, the CRS competencies strategies deployed by Haqs have delivered a CRS value in form of a tool for advertisement. The CRS value tangible picture image of CRS activities from villages in Kenya output has been converted through the enterprise core competencies and dynamic capabilities to innovation in the form of an ethical advert. The use of an ethical advert to promote non-personal communication about Haqs CRS values and its products to targeted customer audiences through a point of sale display are not directly paid for. Thus they represent a cash return on a CRS Investment benefiting financial plan of marketing and sale operational value chain activities. The consequence of reduction in cost of marketing is a measure of operational excellence and a contribution to CVA. Furthermore, the market share of $4 \%$ of local customer's respondent sample attests to CRS drive of brand loyalty. This has contributed to Haqs having a fair share of repurchases towards maintaining of a steady CVA inform of financial turnover (HHCL \& Partners, 2006; Katsoulakos \& Katsoulacos, 2007; Bloomberg, 2012; Egbeleke, 2014).

\subsection{Importance of Business Leader's CRS Values in CRS Performance Delivery}

Analysis of Haqs reveals that CRS Initiatives stemmed out of very strong Islamic religious beliefs. These religion beliefs has helped develop CRS values of the Haqs Directors to the extent that it has shaped CRS programme's design and implementation in such a manner that is similar to what is prevalent among small and medium-size enterprises in Latin America (Vives, 2006). Also, one can see that Haqs' CEO has managed to 
mobilise the boards of directors, managers, and employees to embrace CRS values towards delivery of CRS performance delivery. They attempt to act as ambassadors for values-driven leadership through the selling to suppliers companies CRS initiative that they can use to engage with society (Nelson, 2003). The strong Haqs business leadership CRS values display is contrary to the view held by many that there shouldn't be expectation of any moral epiphanies in the boardrooms of the leading apparel retail corporations with supply chain CRS violations as a consequence (Nova, 2012).

\section{Implications of Strategic CRS Performance Management Model for Business Enterprises CRS Objectives}

The manifestation of cross-industry CRS performance instability is demonstrated by the prevalence of green washing where companies present themselves as ethical without any, or at least a commensurate, change in their CRS values and behaviour (HHCL \& Partners, 2006). Although green washing by companies does produce profit for shareholders through the perverted entrepreneurial system but not CVA to be shared by stakeholders and retained for enterprise survival (Schwab, 2010). The consequences are numerous CRS principles violations within the operational value chain resulting into case settlement fines and penalty in fees and high security costs paid by companies such as examples discussed earlier in this paper (Mallenbaker, 2012; Amunwa, 2012). However, Bloomberg (2012) expressed that CRS principles are important factors in improving business processes and operational efficiency that deliver CRS value. This implies that businesses can only move away from green washing to creation of CVA through new CRS values. New CRS values can be converted into innovation in products, services, processes, markets, alliances and business models capable of changing companies from a mind-set of 'do no harm' to 'do positive good' and from a framework of corporate social responsibility to corporate responsibility and sustainability opportunity (Nelson, 2003). However, better data quality and organisation is needed to ensure that the board of directors and managers see a CRS opportunity and enable execution of strategic CRS performance management decision that delivers CVA (Bloomberg, 2012; Egbeleke, 2013).

The case of Haqs discussed in this paper showed business engagement in economic multiplier CRS programmes can lead to the creation of new CRS values and open up doors of CRS opportunity and contribute to delivery CVA. Even though, it is viewed that most small and medium-sized enterprise, the CRS process is likely to remain informal and intuitive. This is because enterprises such as cooperatives, mutuals, and family -owned business have an ownership and governance structure that can be especially conducive for responsible business conduct. However the only difference between small enterprises such as Haqs and large or multinationals like Wal-Mart, GSK, Shell, and Barclays is the complexities of integration of CRS into business operations (Visser, 2013; EC, 2011). The implication is that if informal and intuitive strategic CRS performance management model processes can deliver Haqs CRS objectives in form CVA, then large companies' operationalization of the model can enable the required integration of CRS values into the business operational value chain. As the model would ensure prevention of CRS value breakdown and limit the use of a management aggressive approach to ensure CRS practice compliance from employees in the case of GSK (Schwab, 2010; Mallenbaker, 2012). Many other companies that appear to have a low market share from the result of the customer perception survey result may be able to convert some percentage of $13 \%$ multiple brand choice customers to themselves by way of improving their brand loyalty though strategic CRS performance management model deployment.

\section{Conclusion}

The build of a strategic CRS performance management model with operability as its main uniqueness represent a new addition to the exiting array of CRS framework. The model is a response to the call for an integrative approach for management of CRS performance instability. Results from the pilot testing reveals model processes support creation of CRS Values from business engagement with society through economic multipliers CRS programme delivery. It enables convertibility of CRS value created into CVA for distribution to stakeholders and business survival towards delivery of overall CRS performances. The CRS performance delivery in turn aids development of pre held CRS Values at business leadership and organisational wide fronts.

\section{References}

Amunwa, B. (2012). Dirty Work: Shell's Security Spending in Nigeria and beyond. London: Platform.

Bhattacharyya, S. S. (2008). Development of a CSR-Strategy-Framework. Corporate Responsibility Research Conference (CRRC) (pp. 1-32). Belfast: Queen's University.

Bloomberg. (2012). How Sustainability Drives Operational Excellence. New York: Bloomberg BusinessWeek Research Services. 
Corporate Citizenship. (2012). Inclusive Business-The Next Frontier for Corporate Responsibility. London: Corporate Citizenship.

Cranfield University. (2013). Corporate Responsibility and Sustainability. Retrieved from http://www.som.cranfield.ac.uk/som/p16919/Knowledge-Interchange/Management-Themes/Corporate-Res ponsibility-and-Sustainability

Creswell, J. W., Plano, C. V. L., Gutmann, M., \& Hanson, W. (2003). Advanced mixed methods research designs. In A. Tashakkori \& C. Teddlie (Eds.), Handbook on mixed methods in the behavioral and social sciences (pp. 209-40). Thousand Oaks, CA: Sage.

DiStefano, J. (2012). Philly Deals: How financial desperados faked the price of money. Retrieved from http://articles.philly.com/2012-07-08/business/32589460_1_community-banks-libor-big-banks

Egbeleke, A. A. (2009). Moving from Economic Recession to Recovery: A Case for Economic Growth Risk (EGR) Strategic Management Model. Proceedings of the Ninth International Scientific School on Modelling for Risk and Safety in Complex System (pp. 134-140). Saint-Petersburg: MASR- Russian Academy of Science.

Egbeleke, A. A. (2010). Transnational Garment Industry Trading Strategies: Unethical Practices and Brand Reputation Risk. In G. Clarkson (Ed.), Business and Organisational Survival and Sustainability (pp. 156-172). Leeds: Leeds University Press.

Egbeleke, A. A. (2013). From Carroll's Pyramid to Elkington TBL: A Move towards Integrated Impact Assessment Driven Corporate Responsibility and Sustainability Performance Reporting System. International Journal of Business Management and Research, 3(4), 93-104.

Egbeleke, A. A. (2014). Determining Strategic Corporate Responsibility and Sustainability Programme Axiom through Set Theory Oriented Filter Elements. Journal of Applied Mathematics in Engineering, Management and Technology, 2(4).

European Commission. (2011). A renewed EU strategy 2011-14 for Corporate Social Responsibility.

Fransen, L. (2012). Multi-stakeholder governance and voluntary programme interactions: Legitimation politics in the institutional design of Corporate Social Responsibility. Oxford Socio-Economic Review, 10(1), 163-192. http://dx.doi.org/10.1093/ser/mwr029

Harvard University. (2007). The role of the private sector in expanding economic opportunity through collaborative action-A leadership dialogue. Corporate Social Responsibility Initiative. Report No. 29, Cambridge, MA: Kennedy School of Government, Harvard University.

Henriques, A. (2010). The Reporting of Non-Financial Information in Annual Reports by the FTSE100. London: CORE.

HHCL and Partners. (2006). The Rough Guide to Responsible Desire. Retrieved from http://www.adliterate.com/archives/2005/03/creating_reposn.html

ILO. (2013). ILO welcomes accord on Building and Fire Safety in Bangladesh. Retrieved from http://www.ilo.org/global/about-the-ilo/activities/statements-speeches/WCMS_213295/lang--en/index.htm

Ivankova, N. V., Creswell, J. W., \& Sheldon, L. S. (2006). Using Mixed-Methods Sequential Explanatory Design: From Theory to Practice. Field Methods, 18(3), 3-20. http://dx.doi.org/10.1177/1525822X05282260

Katsoulakos, P., \& Katsoulacos, Y. (2006a). A multi-dimensional view of corporate responsibility. The 4CR strategic approach to corporate responsibility. CSRQuest working papers.

Katsoulakos, P., \& Katsoulacos, Y. (2006b). Corporate Responsibility and Sustainability Management. The 4CR strategic approach to corporate responsibility. CSRQuest working papers.

Katsoulakos, P., \& Katsoulakos, Y. (2007). Strategic management, corporate responsibility and stakeholder management integrating corporate responsibility principles and stakeholder approaches into mainstream strategy: A stakeholder -oriented and integrative strategic management framework. Journal of Corporate Governance, 7(4), 355-369. http://dx.doi.org/10.1108/14720700710820443

Krauss, C., \& Schwartz, J. (2012). BP Will Plead Guilty and Pay Over \$4 Billion. Retrieved from http://www.nytimes.com/2012/11/16/business/global/16iht-bp16.html?pagewanted=all\&_r $=0$ 
Lacy, P., Cooper, T., Hayward, R., \& Neuberger, L. (2010). A New Era of Sustainability: UN Global Compact-Accenture CEO Study 2010. New York: UN Global Compact-Accenture.

Mallenbaker. (2013). Business Respect: Resources for Corporate Social Responsibility. Retrieved from http://www.mallenbaker.net/csr/CSRfiles/Resources.html

Nelson, J. (2003). Economic Multipliers: Revisiting the core responsibility and contribution of business to development. International Business Leaders Forum, 4.

New York Times. (2013). Bangladesh's Workers Deserve Better. Retrieved from http://www.nytimes.com/2013/08/19/opinion/bangladeshs-workers-deserve-better.html

Nova, S. (2012). Apparel industry outsourcing costs garment workers' lives in Bangladesh. Retrieved from http://www.guardian.co.uk/commentisfree/2012/dec/13/apparel-industry-outsourcing-garment-workers-ban gladesh

Porter, M. E., \& Kramer, M. R. (2006). Strategy \& Society: The Link between Competitive Advantage and Corporate Social Responsibility. Harvard Business Review, 84(12), 56-68.

Robertson, C. (2010). Gulf of Mexico Has Long Been Dumping Site. Retrieved from http://www.nytimes.com/2010/07/30/us/30gulf.html?pagewanted=all\&_r=0

Schwab, K. (2010). A breakdown in our values: Bonuses are a symbol of business's bigger problem-an eroded sense of duty to the wider community. Retrieved from http://www.theguardian.com/commentisfree/2010/jan/06/bankers-bonuses-crisis-social-risk

Schwartz, J. (2013). Rig Owner Will Settle With U.S. in Gulf Spill. Retrieved from http://www.nytimes.com/2013/01/04/business/energy-environment/transocean-settles-with-us-over-oil-spill -in-gulf-of-mexico.html?hp

Teddlie, C., \& Tashakkori, A. (2003). Major issues and controversies in the use of mixed methods in the social and behavioural sciences. In A. Tashakkori \& C. Teddlie (Eds.), Handbook on mixed methods in the behavioural and social sciences (pp. 3-50). Thousand Oaks, CA: Sage.

US-eia. (2012). Country Analysis: Nigeria. Retrieved from http://www.eia.gov/countries/cab.cfm?fips=NI

Visser, W. (2006). Revisiting Carroll's CSR Pyramid: An African Perspective. In E. R. Pedersen \& M. Huniche (Eds.), Corporate Citizenship in Developing Countries (pp. 29-56). Copenhagen: Copenhagen Business School Press.

Visser, W. (2013). Corporate Sustainability \& Responsibility: An Introductory Text on CSR Theory \& PracticePast. London: Kaleidoscope Futures.

Vives, A. (2006). Social and Environmental Responsibility in Small and Medium Enterprises in Latin America. Journal of Corporate Citizenship, 21, 39-50.

WBCSD. (1999). Meeting Changing Expectations: Corporate Social Responsibility. Geneva: World Business Council for Sustainable Development.

Weber, R. P. (1990). Basic content analysis (2nd ed.). New Delhi: Sage Publications.

\section{Copyrights}

Copyright for this article is retained by the author(s), with first publication rights granted to the journal.

This is an open-access article distributed under the terms and conditions of the Creative Commons Attribution license (http://creativecommons.org/licenses/by/3.0/). 